\title{
Growth Effects of Fiscal Deficits in Sri Lanka
}

\section{Mayandy Kesavarajah}

\begin{abstract}
This study examines the economic growth effects of fiscal deficits in the light of policy debates on the Sri Lankan economy during the period 1970 to 2015. More specifically, the study attempts to answer whether the persistent increase in fiscal deficit in Sri Lanka bindered or supported economic growth during the period under review. If it is concluded that economic growth has been negatively affected by fiscal deficits, then the deficits targeting within the Sri Lankan economy becomes extremely important. On the contrary, if fiscal deficits have positively contributed to economic growth, then controlling the size of fiscal deficits becomes expensive in terms of economic development. The empirical evidence in this study confirms that fiscal deficits had an adverse impact on the output growth of the Sri Lankan economy, implying that policy makers needed to control high levels of fiscal deficits to attain the desired levels of growth. The findings further confirm the neoclassical view, which indicates that an increase in fiscal deficits would reduce economic growth, as in the context of the Sri Lankan economy. Moreover, the results reinforce the argument in favour of expeditiously implementing effective strategies for deficit reduction.
\end{abstract}

Key Words: Fiscal deficits, Economic growth and Sri Lanka

JEL Classification: E62, O47 


\section{Introduction}

It is well established in the macroeconomic literatures that maintaining macroeconomic stability is an essential prerequisite for robust and sustainable economic growth. Policy uncertainty created by macroeconomic instability affects growth through the volatility of returns on investment and misallocation of resources as price signals become distorted (Fischer, 1993; and Fatas \& Mihov, 2013). Although the instruments of fiscal policy are widely used to maintain price stability and achieve better financial management (Jayasundara, 1986), the persistently increasing high levels of fiscal deficit have created several repercussions for maintaining macroeconomic stability and emphasised the importance of managing fiscal sustainability in the economies. As large fiscal deficits reduce aggregate savings and may lead to high inflation, high interest rates and balance of payments pressures, with negative growth consequences, much more attention has been widely given to the impacts of fiscal deficit on growth in both developed and developing economies in the recent past. In the aftermath of the global financial crisis, many countries engaged in fiscal and monetary stimuli to revive their economies. In order to revive the economy, the central banks also sharply lowered policy rates, several of them to zero.

The economic theory highlights that there is a clear association between fiscal deficit and economic growth. An increased fiscal deficit leads to an increase in interest rate, which in turn increases the interest rate and reduces investment, and therefore slows down the growth of capital stock and economic activities. Therefore, when fiscal deficit shows a continuously increasing trend over the period, it can considerably reduce a country's capacity to produce goods and services (Saleh, 2003). Furthermore, an increase in the interest rate would result in an exchange rate appreciation, which in turn would create lower net exports and result in trade deficit and a slowdown in economic activities. However, over the period, the experience in many developing economies suggests that although countries attempted to control its level of fiscal deficit, a reduction in fiscal deficit has not always led to a better economic outcome. In particular, if a reduction in fiscal deficit is achieved by a reduction in expenditure, notably through a reduction in development expenditure rather than by an expansion in revenue collection, the long term impact of such a reduction of fiscal deficit may indeed be negative in terms of output growth, which in turn can hinder the creation of public revenues for financing public expenditure.

There has been considerable research inquiry into the causes and nature of differences in growth rates across countries and regions over time. Even small differences in these growth rates, if cumulated over a long period of time, may have substantial impact on the living standards of the people. Despite considerable research on the subject, cross-country and crossregional income disparities are on the rise over time. Understanding the causes behind such inequalities is essential to formulate appropriate policies and bring about required institutional changes to spread the benefits of growth processes across regions. Against this background, 
one important question refers to the economic consequences of a regime of high and potentially persistent fiscal deficit. While the economic growth rate is likely to have a linear negative impact on the fiscal deficit-to-GDP ratio (a decline in the economic growth rate is, ceteris paribus, associated with an increase in the fiscal deficit-to-GDP ratio), high levels of fiscal deficits are likely to be harmful for growth. Potentially, this effect is non-linear in the sense that it becomes relevant only after a certain threshold has been reached.

The channels through which fiscal deficit can potentially affect economic growth are diverse. Several studies in both developed and developing countries have extensively examined the impacts of fiscal deficit on economic growth through various channels. Many studies have focused on the impacts of fiscal deficit on selected macroeconomic variables such as inflation, economic growth, interest rate, exchange rate, private investment, and current account deficit. Although all these macroeconomic variables are crucial in maintaining macroeconomic stability, it is also noted that these variables do play an important role in determining the output growth as well. Nevertheless, although there is no direct relationship between fiscal deficit and economic growth, the possible growth effects of increasing fiscal deficit need to be examined through its implications on other macroeconomic variables. In the case of Sri Lanka, while some studies (Akram, 2012, Jayawickrama, 2006, Jayawickrama, 2004, de Silva, 1992, Jayasundara, 1986) have described the key features of fiscal policy and/or examined the impact of fiscal policy variables on selected economic and social variables such as inflation, unemployment, poverty and equity, to our knowledge, no previous studies have focused on modeling the impacts of fiscal deficit on economic growth and therefore, the present study is expected to address the gap in the literature. Specifically, this study aims to provide fresh theoretical understandings and empirical evidence on the impacts of fiscal deficit on economic growth in Sri Lanka and thereby seeks to provide insights to policy makers to improve the government finances, which could facilitate to expand economic activities and to preserve macroeconomic stability.

The remainder of the paper is organised as follows. Section Two presents the theoretical and empirical evidence on the relationship between fiscal deficits and economic growth. Section Three analyses the historical pattern of fiscal deficits in Sri Lanka, while data, model and estimation results are reported in Section Four. The final section presents the conclusion of the study.

\section{Literature Review}

The review of the existing literature highlights both the theoretical and empirical debate on the impact of fiscal deficit on economic growth. Theoretically, there are three major schools 
of thought ${ }^{1}$ pertaining to the growth effects of fiscal deficit; the neoclassical perspective, the Keynesian perspective, and the Ricardian Equivalence Hypothesis (REH). Fiscal deficit implies a reduction in the level of public saving. According to the neoclassical view, a reduction in national saving can have a negative impact on economic growth if the reduction in government saving is not fully compensated by a rise in private savings. As this could place pressure on domestic interest rates, it can ultimately undermine the level of output in the economy. However, the Keynesian paradigm argued in favour of the positive impacts of fiscal deficit on economic growth through the public expenditure multiplier, which is emphasised as a key policy variable to stimulate growth. More specifically, it asserts that fiscal deficits can enhance savings and investment even when the interest rate rises. This is largely due to the creation of employment opportunities or the utilisation of unutilised human and other resources, which can enhance the productive capacity of the economy. However, at full employment, deficits would lead to crowding out even in the Keynesian paradigm.

The Ricardian equivalence hypothesis advanced by Barro (1989) emphasizes that fiscal deficit is immaterial and claims it is neutral in terms of its impact on growth. It argues that changes between taxes and fiscal deficits do not affect real interest rate, level of investment, and the current account balance. Further, this approach implies that the government's financing decisions do not matter. In this context, the theory emphasizes that policy makers only need to be concerned with the size and composition of public expenditure and revenue to establish the growth effects of fiscal deficits. Considering the importance of these different approaches, some of the relevant empirical studies in this area have been highlighted below.

The theoretical debate has been extended empirically by several studies which have attempted to examine the nexus between the fiscal deficit and economic growth, by using aggregated data. Thus, many empirical literatures on both developed and developing economics has investigated the impact of fiscal deficit on economic activities using various models, including the Vector Auto Regressive (VAR) model. For instance, Vuyyuri et al., (2004), and Buscemi and Yallwe (2012) have explored the case of the India, Fatima et al., (2011) has analyzed the Pakistan economy.

A large number of studies have found positive or negative impacts of fiscal deficit on growth, while few studies have highlighted mixed results. There a number of factors including time dimension, types of countries, types of government administration, the degree of fiscal deficit, and the method of data analysis attributed to various outcomes, in the empirical literature (Rahman, 2012). These contrasting approaches have resulted in many discussions on both developed and developing economies on the role of fiscal deficit in the process of economic

\footnotetext{
${ }^{1}$ While the neoclassical and Ricardian schools focus on the long run; the Keynesian view focuses on the short run effects.
} 
growth over the period. Considering the importance of these different approaches, relevant empirical studies in this area have been discussed below.

Vuyyuri et al. (2004) examined the relationship between the fiscal deficit of India with other macroeconomic variables such as nominal effective exchange rate, GDP, consumer price index and money supply (M3), using a cointegration approach and Vector Error Correction Models (VECM) over the period 1970 to 2002. The author concludes that there is a bi-directional causality between fiscal deficit and nominal effective exchange rates. However, the study did not find any significant relationship between fiscal deficit and other variables namely GDP, money supply and consumer price index. In addition, the researcher found despite the fiscal deficit was Granger caused by GDP, but the fiscal deficit did not have any reciprocal relationship.

Buscemi and Yallwe (2012) analysed the effects of fiscal deficit on the sustainability of economic growth for three emerging countries: China, India and South Africa, using the reduced form of Generalized Method of Moment's (GMM) method for dynamic panel data over the period 1990-2009. They found that the coefficients for fiscal deficit results are significant and positively correlated to economic growth. Bose et al. (2007) also found similar results using panel data for the period 1970 to 1990, for 30 developing countries. They suggested that fiscal deficit had a positive impact on the growth rate and highlighted that it was mainly as a result of increased productive expenditure such as education, health and capital expenditure.

However, some of the studies in this field have cited the negative impacts of fiscal deficit on economic growth. Fatima et al. (2011) studied the impact of government fiscal deficit on investment and economic growth using time series data from 1980 and 2009, in Pakistan. The study showed the negative impacts of fiscal deficit on economic growth. They also found that fiscal deficit creates many problems such as high levels of inflation, current account deficit, and high level of debt in the economy. Fatima et al (2012) again investigated the impact of the fiscal deficit on economic growth in Pakistan using time series data over the period 1978 to 2009. The findings showed a negative impact of fiscal deficit on economic growth and suggested that the government avoid certain levels of the fiscal deficit to achieve the desired level of economic growth. Huynh (2007) concluded a negative impact of fiscal deficit on the GDP growth by analyzing the trends in budget deficit and economic growth in Vietnam over the period of 1990 to 2006. A study conducted by the International Monetary Fund (IMF) during the mid-1980s on a group of developing countries also concluded that countries with high fiscal deficit had significantly lower economic growth than countries with low to medium fiscal deficits.

Similarly, Rahman (2012) examined the relationship between fiscal deficit and economic growth in Malaysia by employing quarterly data over the period 2000 to 2011. Although the author found that there was no long term relationship between fiscal deficit and growth, which 
is consistent with the Ricardian equivalence hypothesis, ${ }^{2}$ he showed that expenditure had a positive and significant impact on long term growth. Similarly, Fatima et al. (2011) also examined the impact of government fiscal deficit on investment and economic growth in Pakistan using time series data over the period 1980 to 2009. The study found that increasing fiscal deficit has undermined the growth objectives and thereby adversely affected the physical and social infrastructure within the economy.

Keho (2010) investigated the causal relationship between fiscal deficit and economic growth in the seven member countries of the West African Economic and Monetary Union using time series data. The empirical evidence showed mixed results. In three cases, the study did not find any causality between fiscal deficit and growth. However, in the remaining four countries, the author found that deficits had adverse effects on economic growth. These findings led to support the budgetary rule, aiming at obtaining positive total budget surplus as a prerequisite for sustainable growth and real convergence within the monetary union.

Vazquez and Rider (2006) examined the effects of fiscal decentralization for two fast growing emerging economies namely, India and China and the study concluded that neither country is fully using the potential of fiscal decentralization to improve allocation of resources and attain their growth potentials. Although both countries experience high rates of growth, the pace and the quality of the growth could have been even higher if appropriate fiscal reforms were undertaken in their inter-governmental fiscal systems.

\section{Historical Patterns of Fiscal Deficits in Sri Lanka}

Fiscal deficits in Sri Lanka rose significantly over the past decades and this trend was generally accompanied by an expansion in the size of the government. The government's budget is primarily used as a mean of mobilizing resources to promote economic growth, as a mean of attaining social welfare objectives and as an instrument of demand management policies (Jayasundara, 1986). In this regard, fiscal deficit refers to the excess of the public sector's spending over its revenue. According to Jhingan (2002), the phrase "deficit financing" is used to mean any public expenditure that is in excess of current revenues. Similarly, fiscal capacity determines a country's ability "to finance larger fiscal deficits without creating any problem for macroeconomic stability and debt sustainability" (World Bank, 2009). However, a continually increasing high level of fiscal deficit in a developing economy like Sri Lanka would create a severe issue in maintaining macroeconomic stability. Moreover, a higher level of fiscal deficits implies the requirements of high government borrowing and high debt servicing, which in turn can place pressure on the government to reduce its expenditure on certain sectors such as health, education and infrastructure in order to control the increasing fiscal

\footnotetext{
${ }^{2}$ Ricardian equivalence hypothesis claimed that there is neutral relationship between budget deficit and economic growth.
} 
deficit and to maintain internal stability. However, it is also noted that a reduction in these expenditures can reduce the level of human as well as physical capital in an economy which can positively contribute towards the long term growth rate.

Figure 1: Fiscal Deficit in Sri Lanka (Percentage of GDP)

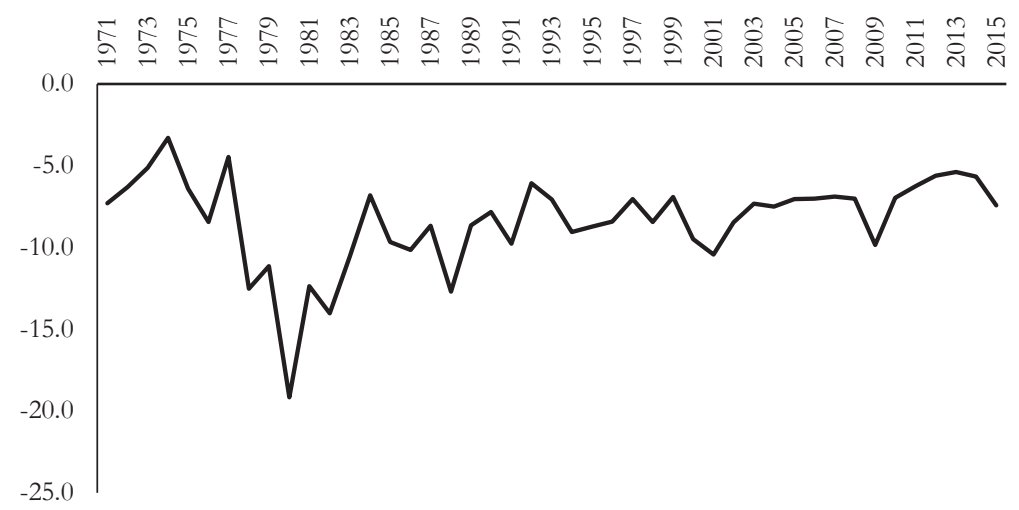

Source: Central Bank of Sri Lanka

The Figure 1 above presents the trend of fiscal balance as a percentage of GDP during the period 1970 to 2015 in Sri Lanka. Despite the country having experienced a positive fiscal balance during the 1950s, the economy was marked by a significant change in its fiscal activities with the increasingly negative trend of revenue and expenditure following the economic liberalisation, As a result of high levels expenditure resulting in expenditure revenue gaps, fiscal balance has remained highly volatile under the period reviewed in this study.

Reinhart and Rogoff (2010) argue that war debts may be less problematic for future growth, partly because the high war-time government spending comes to a halt as peace returns, while peacetime debt explosions may persist for longer periods of time. The accumulation of government fiscal deficit during 1983-2008 was mainly in relation to the war. A large fiscal deficit took place in 1980, which was 19.2 per cent of GDP and then it gradually decreased to 6.8 per cent in 1984. However, this positive tendency appeared temporary and the fiscal deficit to GDP ratio moved slowly up in the succeeding years, to 9.7 per cent in 1985 and 12.7 per cent in 1988. The significant increase in fiscal deficit was mainly driven by decreased government revenue ${ }^{3}$ and increased public expenditure, especially on food subsidy and defense. Further, a sharp increase is noted after the mid-1980s as a consequence of the massive increase in public expenditure on infrastructure during the initial stage of trade liberalisation. However, the most noticeable trend persisting over the recent five years has been a decline in

\footnotetext{
${ }^{3}$ This can be due to narrow tax base and inefficiency of tax collection in Sri Lanka.
} 
total fiscal deficit as percentage of GDP, which decreased from 10.4 percent in 2001 to 7.0 per cent in 2010 and then decreased again to 5.4 per cent in 2013. Improvement in both revenue and expenditure contributed to this noteworthy achievement. Government revenue exceeded the target, while expenditure was maintained within the original budgetary allocation, narrowing the government's gap and reducing the government's financing requirements (CBSL, 2010). Therefore, in recent years, Sri Lanka has experienced fiscal deficits ranging from 6 per cent to 9 per cent of GDP between 2006 and 2015. Although the fiscal deficit declined to around 7.4 per cent of GDP in 2015, it is still considered to be a major issue faced by the economy in maintaining its macroeconomic stability. ${ }^{4}$ Hence, a significant rise in government revenues is necessary to maintain fiscal sustainability and achieve the government's economic targets.

The objective of government financing is to mobilize financial resources, taking into account elements of cost and risk as well as any macroeconomic and monetary implications (MontfortMlachila et al., 2002). Further, the impact of fiscal deficit on economic growth is theoretically explained through the effect of fiscal deficit on the flow of money into the economy and through the supply side. ${ }^{5}$ The more government expenditure exceeds revenue the more money will be circulated in the economy, which leads to higher employment and output (McCandless, 1991). On the other hand, the larger amount of public borrowing can also crowd out private investment. Nevertheless, issues arise when a government needs to finance its fiscal deficit, which has been generated as a result of current expenditure rather than the capital expenditure.

While an economy can finance its fiscal deficit through domestic as well as foreign sources, these could generate negative consequences on other macroeconomic variables. For instance, fiscal deficit, which is financed by the Central Bank, can lead to inefficiencies in financial markets and can cause high inflation ${ }^{6}$ in the economy (Shojai, 1999); on the other hand, bond financing of fiscal deficit can lead to a rise in interest rates, which in turn can crowd out private investment. Furthermore, increasing fiscal deficits can also distort the real exchange rate, which in turn undermines the international competitiveness of the economy and thereby generates external imbalances. Hence, the problems arise when the deficit level becomes too high and there is a persistent need to finance it.

\footnotetext{
${ }^{4}$ High fiscal deficit has increased aggregate demand results an inflationary pressures and higher external current account deficits.

${ }^{5}$ Fiscal deficit used for creating infrastructure and human capital will have a different impact than if it is used for financing targeted subsidies and recurrent expenditure.

${ }^{6}$ However, government expenditure on productive development projects in developing countries will not create inflationary situation in the economy since it can be assumed this projects generates greater output in the economy and in turn leads to lower the price level (Rao, 1953).
} 


\section{Empirical Model, Data and Methodology}

This study uses time series annual data over the period from 1970 to 2015 . All the data used in this study have been obtained from various issues of the annual report of the Central Bank of Sri Lanka. The empirical growth model used in this study is based on a conditional convergence equation, ${ }^{7}$ which indicates that the GDP growth rate depends on the initial level of income per capita, the investment-to-GDP rate and the population growth rate. However, as the present study mainly attempts to examine the impact of fiscal deficits on growth, the above convergence model was augmented to include the level of fiscal deficit (as a share of GDP) and other related variables. Other control variables that were included into the growth equation were the long-term real interest rate (to capture the impact of inflation and the effects of the fiscal-monetary policy mix), indicators for the openness ${ }^{8}$ of the economy. This would help to expand the model beyond a closed-economy.

The basic estimation equation is as follows:

$$
\begin{gathered}
g_{i t+k}=\alpha_{0}+\alpha_{1} \ln P C G D P_{i t}+\alpha_{2} F D_{i t}+\alpha_{3} F D^{2}{ }_{i t}+\alpha_{4} G C F_{i t} \\
+\alpha_{2} P O G_{i t}+\alpha_{3} O P P_{i t}+\alpha_{4} L I R_{i t}+\varepsilon_{i t} \ldots(1)
\end{gathered}
$$

The above equation measures the direct effect of fiscal deficits on economic growth. In general, most of the time series variables are nonstationary, containing a unit root. A standard regression with nonstationary data can lead to the problem of spuriousness, which can occur when two time series variables in a regression are highly correlated although there is no actual relationship between them. High correlation is due to the existence of a time trend in both time series variables. In an attempt to avoid the spurious problem, the difference of the variables has to be included for the cointegration analysis.

\footnotetext{
${ }^{7}$ Convergence refers to the process by which relatively poorer regions or countries grow faster than their rich counterparts. Conditional convergence implies that a country or a region is converging to its own steady state.

${ }^{8}$ The sum of export and import shares in GDP.
} 
Table 1: Data Description and Sources

\begin{tabular}{lcc}
\hline \hline \multicolumn{1}{c}{ Variable } & Variable Description & Source \\
Abbreviation & Growth rate of GDP & \\
\hline ECGDP & Natural logarithm of the level of GDP per capita & CBSL \\
$F D$ & Fiscal deficits as a share of GDP & CBSL \\
GDCF & Gross domestic capital formation as a share of & CBSL \\
POG & Gop & CBSL \\
OPP & Openness (Sum of exports and imports $(\%$ of & CBSL \\
& GDP) & \\
LIR & Long term interest rate & CBSL \\
PCR & Private Sector Credit (percent of GDP) & CBSL \\
$\varepsilon_{i t}$ & Error term & \\
\hline
\end{tabular}

The first step for cointegration test is to examine the stationery properties of all the variables. The Augmented Dickey Fuller (ADF) and Phillips Perron (PP) tests are employed to examine the order of integration of each time series variable. The unit root test was conducted both for the levels and the first difference of each series. Meanwhile, the Johanson and Juseliues (1990) method was used to examine the long run relationship among the variables selected in this study. The impulse response function was used to examine the dynamics of the selected variables in response to various shocks. Furthermore, the Granger causality test was used to determine whether one time series is useful in forecasting another. The optimal lag length that was selected in this study was based on lag order selection criteria (AIC or SBC) that minimize the overall sum of squared residuals or maximizes the likelihood ratio. The descriptive statistics of the variables used in this study are given in Appendix Table A1.

\section{Results and Discussion}

\subsection{Impact of Fiscal Deficits on Economic Growth}

This section investigates the direct impact of fiscal deficits on economic growth in Sri Lanka covering the period 1970-2015, employing annual time series data published in the various annual reports of the Central bank of Sri Lanka. Further, the unit root test results are provided in Appendix Table A2. 
Table 2: VAR Lag Order Selection Criteria ${ }^{9}$

\begin{tabular}{ccccccc}
\hline \hline Lag & LogL & LR & FPE & AIC & SC & HQ \\
\hline 0 & -617.6300 & NA & 19520.32 & 29.74429 & 30.03390 & 29.85044 \\
1 & -461.9683 & $252.0238^{*}$ & 125.5855 & 24.66516 & $26.98205^{*}$ & 25.51439 \\
2 & -416.1214 & 58.94603 & 177.8009 & 24.81530 & 29.15948 & 26.40761 \\
3 & -350.8009 & 62.20998 & 145.7248 & 24.03814 & 30.40959 & 26.37353 \\
4 & -263.4270 & 54.08861 & $95.88180^{*}$ & $22.21081^{*}$ & 30.60955 & $25.28928^{*}$ \\
\hline
\end{tabular}

Note: $*$ indicates lag order selected by the criterion

Table 2 presents the results of VAR lag order selection criteria. According to the Sequential modified LR test statistic (LR), Final Prediction Error (FPE), Akaike Information Criterion (AIC), Schwarz Information Criterion (SC), and Hannan-Quinn information criterion (HQ) suggest that the optimum lag order for VAR in this model is four. Therefore the subsequent analyses in this study were based on four lags. ${ }^{10}$

Table 3: Johansen Cointegration Rank Test (Trace)

\begin{tabular}{ccccc}
\hline \hline $\begin{array}{c}\text { Hypothesized } \\
\text { No. of CE(s) }\end{array}$ & Eigenvalue & $\begin{array}{c}\text { Trace } \\
\text { Statistic }\end{array}$ & $\begin{array}{c}0.05 \\
\text { Critical Value }\end{array}$ & Prob.** \\
\hline None ${ }^{*}$ & 0.795973 & 178.7523 & 125.6154 & 0.0000 \\
At most 1 & 0.613018 & 110.4036 & 95.75366 & 0.0034 \\
At most 2 & 0.472546 & 69.58042 & 69.81889 & 0.0522 \\
At most 3 & 0.397230 & 42.07356 & 47.85613 & 0.1567 \\
At most 4 & 0.291797 & 20.30612 & 29.79707 & 0.4023 \\
At most 5 & 0.104193 & 5.470087 & 15.49471 & 0.7570 \\
At most 6 & 0.017035 & 0.738804 & 3.841466 & 0.3900 \\
\hline
\end{tabular}

Note: Trace test indicates 2 cointegrating equations at the 0.05 level, $*$ denotes rejection of the hypothesis at the 0.05 level, **MacKinnon-Haug-Michelis (1999) p-values

\footnotetext{
${ }^{9}$ The endogenous variables considered in this study to examine the optimal lag are economic growth rate, fiscal deficit as a percentage of GDP, private sector credit as a percentage of GDP, population growth rate, openness, investment as a percent of GDP and long term interest rate.

${ }^{10}$ Since the number of observations in the time series was 46, with the purpose of avoiding the degrees of freedom problem the maximum number of lags was selected as four in the study.
} 
Table 4: Johansen Cointegration Rank Test (Maximum Eigenvalue)

\begin{tabular}{ccccc}
\hline \hline $\begin{array}{c}\text { Hypothesized } \\
\text { No. of CE(s) }\end{array}$ & Eigenvalue & $\begin{array}{c}\text { Max-Eigen } \\
\text { Statistic }\end{array}$ & $\begin{array}{c}0.05 \\
\text { Critical Value }\end{array}$ & Prob.** \\
\hline None ${ }^{*}$ & 0.795973 & 68.34870 & 46.23142 & 0.0001 \\
At most $1 *$ & 0.613018 & 40.82322 & 40.07757 & 0.0411 \\
At most 2 & 0.472546 & 27.50686 & 33.87687 & 0.2372 \\
At most 3 & 0.397230 & 21.76744 & 27.58434 & 0.2325 \\
At most 4 & 0.291797 & 14.83603 & 21.13162 & 0.3005 \\
At most 5 & 0.104193 & 4.731283 & 14.26460 & 0.7753 \\
At most 6 & 0.017035 & 0.738804 & 3.841466 & 0.3900 \\
\hline
\end{tabular}

Note: Max-eigenvalue test indicates 2 cointegrating equations at the 0.05 level, ${ }^{*}$ denotes rejection of the hypothesis at the 0.05 level, ${ }^{* *}$ MacKinnon-Haug-Michelis (1999) p-values

The trace statistic and maximum Eigen value given in Tables 3 and 4 suggest that there exist at least 1 cointegrating vector among the seven variables considered in equation 1 . The findings of this cointegrating vector imply that there exists a stable long-run equilibrium relationship between the economic growth, investment, fiscal deficits, long term interest rate, openness and growth rate of the population during 1970 to 2015 in the Sri Lankan economy.

Table 5: Estimated Long Run Equation

\begin{tabular}{ccccc}
\hline \hline Variable & Coefficient & Std. Error & t-Statistic & Prob. \\
\hline C & -12.9719 & 8.10504 & -1.60048 & 0.1178 \\
PCGDP & 0.75795 & 0.58719 & 1.29080 & 0.2046 \\
FD & -0.13005 & 0.46396 & -0.28029 & 0.7808 \\
FD & -0.01646 & 0.02273 & -0.72403 & 0.4735 \\
GCF & $0.24999 * * *$ & 0.08274 & 3.02129 & 0.0045 \\
POG & $0.76749 *$ & 0.39104 & 1.96269 & 0.0570 \\
OPP & 1.02604 & 0.64912 & 1.58066 & 0.1222 \\
LIR & 0.10216 & 0.07169 & 1.42519 & 0.1623 \\
& 0.42401 & Mean dependent var & 4.83695 \\
R-squared & 1.69232 & Akaike info criterion & 4.04686 \\
S.E. of regression & 108.831 & Schwarz criterion & 4.36488 \\
Sum squared resid & -85.0777 & F-statistic & 3.99623 \\
Log likelihood & 1.86831 & Prob(F-statistic) & 0.00229 \\
Durbin-Watson stat & Least Squares & Included observations & 46 \\
Method & \multicolumn{2}{c}{$\quad$}
\end{tabular}

Dependent Variable: Growth Rate of GDP.

Note: *,**, and $* * *$ imply the significance at $10 \%, 5 \%$ and $1 \%$ respectively. 
As summarised in Table 5, we find that the annual change in the gross domestic capital formation (investment) is statistically significant and positively associated with the economic growth. This implies that investment plays an important role in expanding economic activities in the Sri Lankan economy. Meanwhile, the study also finds that the population growth in Sri Lanka has a positive and statistically significant impact on the output growth. Turning to the fiscal deficits variable, somewhat surprisingly, no direct and significant impact of fiscal deficits, on economic growth is found; rather the impact may be indirect through the channel of long term interest rates. Increased deficits may increase interest rates and thus slow down economic growth. At the initial analysis, as the usage of fiscal deficits in a linear form does not yield significant results, we used a quadratic equation in fiscal deficits which would help to understand whether there exists a non-linear impact of fiscal deficits on growth. However, a nonlinear relationship between fiscal deficits and economic growth cannot be identified from the above results. Although the estimations of the long run regression demonstrates that the impact of fiscal deficits on growth is insignificant, the impulse response function and Granger causality test could be used to examine the possible impact of fiscal deficits on growth.

\subsection{Temporary Shocks to Fiscal Deficits}

While the economic growth rate is likely to have a linear negative impact on the fiscal deficitsto-GDP ratio, high levels of fiscal deficits are also likely to be harmful for economic growth, but potentially after a certain threshold has been reached. From a policy perspective, a negative impact of fiscal deficits on economic growth strengthens the arguments for ambitious deficits reduction through fiscal consolidation. This section seeks to examine this relationship using the impulse response function, which describes the dynamic behavior of the variables. Further, this function exhibits reactions of endogenous variables to shock from error term in equation.

Figure 2 depicts dynamic response functions following a temporary fiscal deficits shock equal to a one-percentage point increase in standard deviation. All dynamic responses are shown as percentage-point deviations from steady state. The behavior of the impulse response functions following a fiscal deficits shock are in line with our expectations. An increase in fiscal deficits generate a negative effect on economic growth. Economic growth increases immediately after the shock and stays negative for a sustained period of time in the medium to long term, although it has a positive impact on growth in the short term. This indicates that an increase in the fiscal deficits as a proportion of GDP decreases economic growth in the case of the Sri Lankan economy. The negative effect of fiscal deficits on economic growth appears to be in line with the neoclassical growth model developed by Solow (1956) and Swan (1956), which indicates that an increase in fiscal deficits would reduce economic growth.

The above negative impacts of fiscal deficits on economic growth in the case of the Sri Lankan economy can be explained from two channels. First, this might be as a result of increases in unproductive expenditure such as defense, subsidy and interest payments in the economy. 
Secondly, this may be as a result of an impact of fiscal deficits on other macroeconomic variables such as interest rate, inflation and exchange rate. The negative effects of fiscal deficits on economic growth could be partly due to the nature of financing mechanisms adopted by the government to fulfill its deficits and financing requirements during the period under review, which is dominated by domestic sources especially from market and non-market borrowings. Thus, the findings suggest that the government should avoid high levels of fiscal deficits in order to achieve the desired level of growth. However, since the scope of this study is limited only to fiscal deficits and economic growth, the findings of this study paves the way to explore the overall effect of fiscal deficits on all other variables in the future. This modelbased finding runs somewhat counter to Eisner and Pieper is (1987), finding regarding the positive impact of fiscal deficits on economic growth in the United States and other OECD countries. However, the findings of this study seems consistent with some other studies such as Fatima et al. (2011) who find negative impacts of fiscal deficits on economic growth, and show that fiscal deficits create many macroeconomic problems in the economy, such as high levels of inflation, current account deficits, and high level of debt which hinder the expansion of economic activities. The behavior of the rest of the impulse response functions also accord well with intuition.

Although our main objective is to identify the impact of fiscal deficits on economic growth, the analysis on the response of economic growth following temporary shocks in macroeconomic aggregates would provide some insights with regard to the nexus among the variables considered in this study. The literature on the macroeconomic impacts of various shocks on economic growth is relatively scarce in the case of the Sri Lankan economy and therefore discussion on the impacts of macroeconomic variables on economic growth can also provide a useful benchmark for future analysis in this area. 
Figure 2: Dynamic Responses to Fiscal Deficits Shock
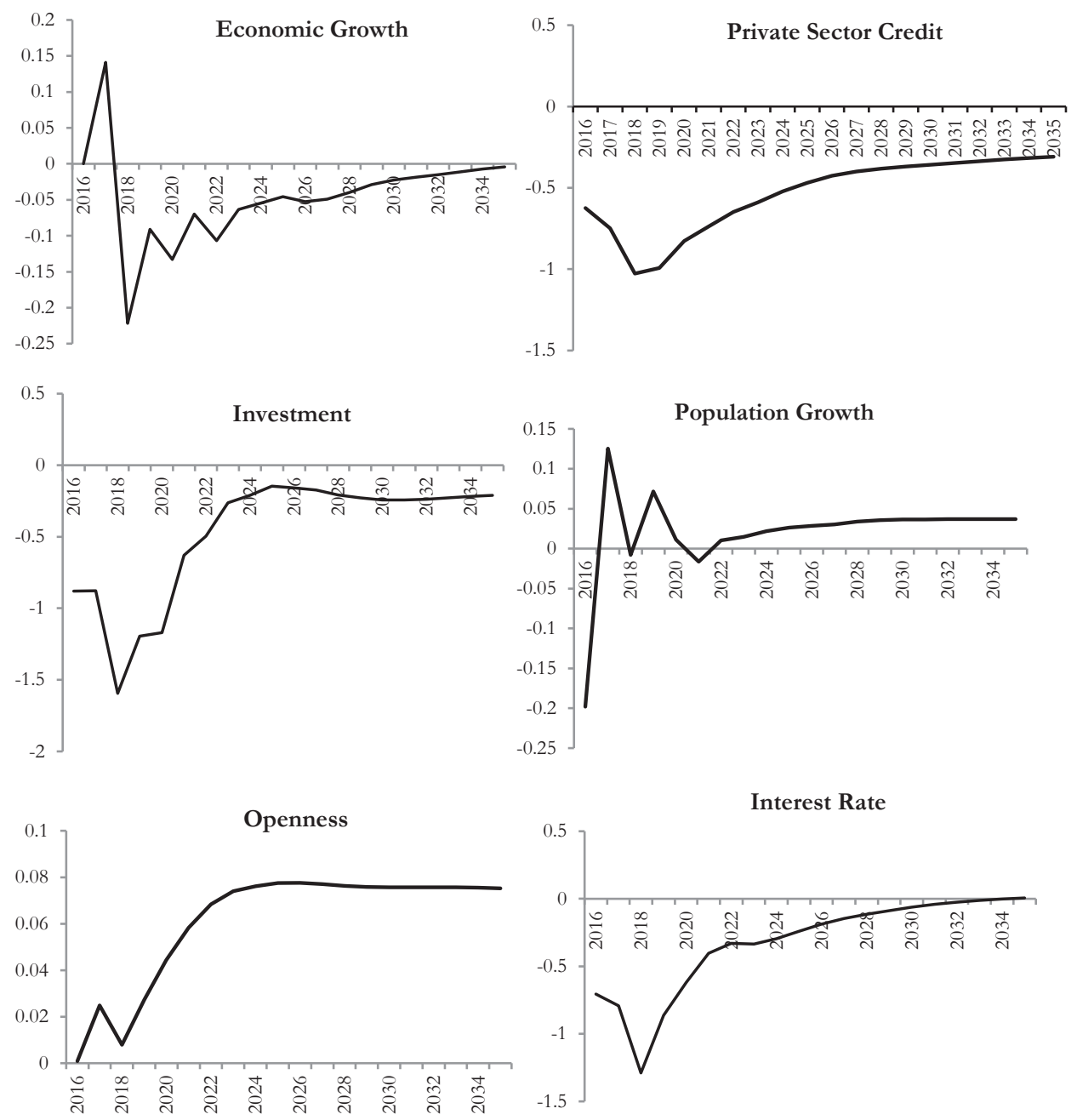

Source: Authors' Calculation

Note: All dynamic responses are reported as percentage point deviations from steady state

Figure 3 depicts dynamic response functions following a temporary shock, equal to a onepercentage point increase in steady state output on selected variables considered in this study. All dynamic responses are shown as percentage-point deviations from steady state. A positive impulse in private sector credit determines a small increase of economic growth in the short term. However, in the medium it tends to move towards the negative and takes about five years to reach the steady state level. Meanwhile, it is found that the effect on economic growth 
in response to a monetary policy shock, indicated by increased long term interest rates, temporarily move downward in the short term and, however, it takes about four years to reach its steady state level and then it has a positive impact on the output growth in the medium term. Meanwhile, the decline in interest rates following the fiscal deficits shock has important qualitative and quantitative implications for the behavior of the rest of the variables in the model.

Figure 3: Dynamic Responses to Selected Shocks (per cent deviation from baseline)

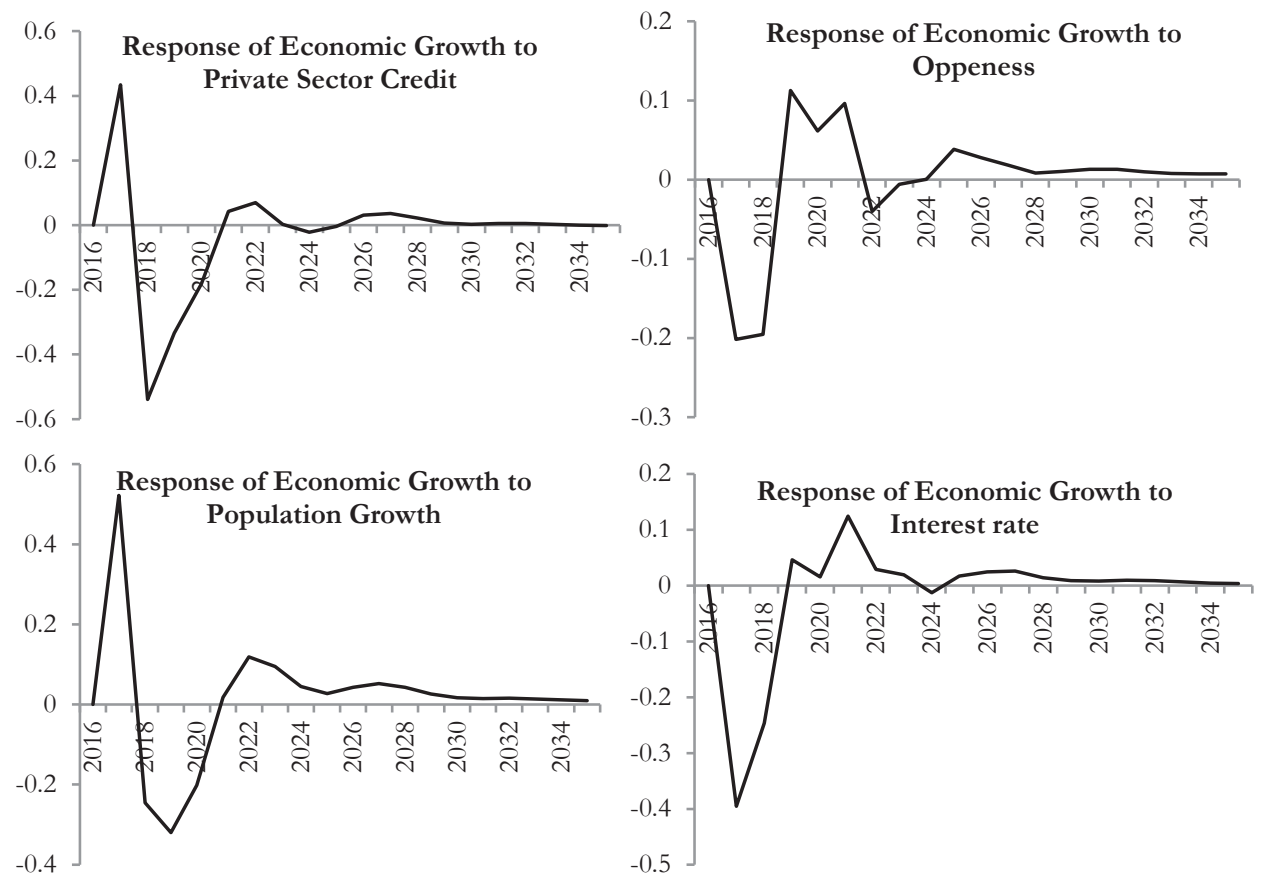

Source: Authors' Calculation

Note: All dynamic responses are reported as percentage point deviations from steady state.

Meanwhile, the Granger causality test was also conducted with the view to examine the leadlag relationship among the variables considered in this study. The results are reported in Appendix Table A4. The estimated results indicate that the null hypothesis of "Fiscal deficits do not Granger cause economic growth" cannot be rejected even at 10 per cent level of significance in all three lags considered in this study. At the same time, all other variables are not found to be Granger causing economic growth in pairs and jointly. Therefore, the empirical results derived from the Granger causality test do not reveal any causality between economic growth and the determinants. However, this study could be further extended by considering the composition of financing sources more intensively, which can help policy 
makers gain a deeper understanding about the relationship between fiscal deficits and economic growth.

\section{Conclusion}

This paper examined the impact of fiscal deficits on growth in the small open economy of Sri Lanka over the period 1970 to 2015. Empirical evidence based on the impulse response function showed that the response of output in the long run with regard to an increase in fiscal deficits shock is negative. This demonstrates that the increased fiscal deficits, which had undermined the growth prospects while putting an additional burden on fiscal sustainability, had a significant and long term impact on growth, implying that policy makers avoid high levels of fiscal deficits in order to achieve desired levels of growth. The study also confirms the existence of the neoclassical view in the context of the Sri Lankan economy. Moreover, the results led to an additional argument in favour of expeditiously implementing ambitious strategies for deficits reduction. However, the key issue is the response of private investment to a change in the fiscal deficits. If private investment rises by the same amount as fiscal deficits rise, then there is no change in national saving and no further adjustments would be required. Further, while revenue measures should focus on minimizing distortions, expenditure reforms should primarily address inefficiencies in spending. Such policies would not only provide fiscal space, but also contribute directly to medium to long term growth. 


\section{References}

Akram, N. (2012). "Fiscal Scenario of South Asian Countries: Implications for Economic Growth and Poverty Alleviation". Science Journal of Economics2012 (2).

Ball, L. and Mankiw, N. G. (1995). "What do budget deficitss do?" Harvard Institute of Economic Research. Working Papers. 1740: pp. 95-119.

Barro, R. J. (1987). "Government Spending, Interest rates, Prices, and Budget Deficits in the United Kingdom 1701-1918”. Journal of Monetary Economics 20(3): pp. 221-224.

Barro, R.J., (1989). 'The Ricardian Approach to Budget Deficits". The Journal of Economic Perspectives 3 (2): pp. 37-54.

Bose, N. Haque, M.E. and Osborn, D.R. (2007). "Public Expenditure and Economic Growth: A disaggregated Analysis for Developing Countries". The Manchester School.75 (5): pp. 533-556.

Buscemi, A and Yallwe, A. H. (2012). "Fiscal Deficit, National Saving and Sustainability of Economic Growth in Emerging Economies: A Dynamic GMM Panel Data Approach". International Journal of Economics and Financial Issues. 2 (2): pp.126140.

Central Bank of Sri Lanka, Annual Reports, Various Years.

Devarajan, S. Swaroop, V. and Zou, H. F. (1996). "The Composition of Public Expenditure and Economic Growth". Journal of Monetary Economics. 37 (2): pp. 313-344.

Dickey, D.A. and Fuller, W.A. (1979). Distribution of the Estimators for Autoregressive Time Series with a Unit Root. Journal of the American Statistical Association 74:pp. 427431.

Dornbusch, R and Fisher, S, (1990), "Macroeconomics", 5 th Edition, McGraw - Hill Publishing Company, pp711-745.

Dwivedi, D N, (2010). "Macroeconomics: Theory and Policy". $3^{\text {rd }}$ Edition, Tata McGraw Hill Education Private Limited New Delhi.

Easterly, W.Rebelo, S. (1993). "Fiscal Policy and Economic Growth: an Empirical Investigation". Journal of Monetary Economics 32: pp. 417-57.

Engen, E and Skinner, J. (1992). "Fiscal Policy and Economic Growth", NBER Working Paper, No.4223. Cambridge.

Engle R. F. and Granger, C. W. J. (1987). "Cointegration and Error Correction: Representation, Estimation, and Testing”. Econometrica. 55 (2): $\quad$ pp. 251-276.

Fatima, G. Ahmed, A. M. and Rehman, W. U. (2011). "Fiscal Deficit and Economic Growth: An Analysis of Pakistan's Economy". International Journal of Trade, Economics and Finance. 2 (6): pp: 501-504.

Fatima, G. Ahmed, M. and Rehman, W. U. (2012). "Consequential Effects of Budget Deficit on Economic Growth of Pakistan". International Journal of Business and Social Science 3 (7).

Granger, C. W. J. (1981). "Some Properties of Time Series Data and their use in Econometric Model Specification". Journal of Econometrics. 16 (1): pp. 121-130.

Gujarati, D. (1995). "Basic Econometrics”.Mc.Graw-Hill International Edition, NewYork, NY, USA, 3rd edition.

Harris, R and R. Sollis (2003).“Applied Time Series Modeling and Forecasting”. Jhon Wiley and Sons, schchester.

Huynh, N. D. (2007). "Budget Deficit and Economic Growth in Developing Countries: The case of Vietnam". Kansai Institute for Social and Economic Research (KISER). 
Jayasundera, P B (1986). "Fiscal Policy in Sri Lanka since Independence", in Rasaputra et al (eds), Facets of Development in Independent Sri Lanka - Ronnie de Mel Felicitation Volume, Colombo: Ministry of Finance and Planning.

Jayawickrama, A. (2006). "Essays on fiscal sustainability and tax smoothing, and fiscal policy simulation experiments for Sri Lanka”. A PhD thesis submitted to the National University of Singapore, Singapore.

Jayawickrama, A. (2004). "Fiscal policy sustainability: Evidence from Sri Lanka". Sri Lanka Economic Journal 5(1): pp. 55-74.

Jhingan, M. L. (2002). "The Economics of Development and Planning". New Delhi: Vrinda Publications Ltd. World Bank (2005). Reaching the Poor: What Works, What doesn't? Washington DC: World Bank.

Johansen, S. and Juselius, K. (1990). "Maximum Likelihood and Inference on Cointegration with Applications to the Demand for Money". Oxford Bulletin of Economics and Statistics, 52(3): pp.169-210.

Keho, Y (2010). "Budget Deficits and Economic Growth: Causality Evidence and Policy Implications for WAEMU Countries". European Journal of Economics Finance and Administrative Sciences 18.

Kesavarajah, M (2011). "Determinants of Inflation in Sri Lanka after Economic Liberalization: An Econometric Analysis", Annual Research Symposium Proceedings, University of Colombo.

Kesavarajah, M and Ravinthirakumaran N, (2011). "The Impacts of Government Expenditure on Economic Growth in Sri Lanka: An Econometrics Analysis", Conference Proceedings of Eighth International Conference on Business Management, University of Sri Jayewardenepura, Sri Lanka: pp. 163-168.

Keynes, J. M. (1936).“General Theory of Employment, Interest and Money”. Harcourt, Brace and Co, New York, NY, USA.

Mankiw, N.G., D. Romer, and Weil, D. N, (1992). "A contribution to the empirics of Economic Growth”. Quarterly journal of Economics. 107 (2), pp. 407-437.

Perron, P. (1988). "Trends and Random Walks in Macroeconomic Times Series: Further Evidence from a New Approach". Journal of Economic Dynamics and Control 12: pp. 297-332.

Phillips, P. C. B. and Perron, P. (1988). “Testing for a Unit Root in Time Series Regression”. Biometrika75 (2):pp. 335-346.

Rahman, N. H. A. (2012). "The Relationship between Budget Deficit and Economic Growth from Malaysia's Perspective: An ARDL Approach”. Business Innovation IPEDR vol.38, IACSIT Press, Singapore.

Rebelo, Sergio (1991). “Long-Run Policy Analysis and Long-Run Growth,” Journal of Political Economy, 99 (June).

Saleh, S. A. (2003). “The Budget Deficit and Economic Performance”. University Wollongong Economics Working Paper Series 03-12: 1-55.

Shojai, S. (1999). "Budget Deficits and Debt: A Global Perspective" (2nd ed.). New York, USA: Praeger Publishers.

Solow, R.M. (1956). "A Contribution to the Theory of Economic Growth". The Quarterly Journal of Economics.70 (1): pp. 65-94.

Swan, T. (1956). "Economic Growth and Capital Accumulation". Economic Record 32: pp. 344-361. 
Appendix

Table A2: Descriptive Statistics

\begin{tabular}{cccccccc}
\hline \hline & EG & FD & LIR & GDCF & OPP & POG & PCR \\
\hline Mean & 4.8369 & -8.2964 & 11.4367 & 24.7239 & 1.9983 & 1.1776 & 20.7611 \\
Median & 4.9500 & -7.4572 & 11.0400 & 24.7500 & 1.3767 & 1.3396 & 22.5218 \\
Maximum & 9.1000 & -3.2939 & 21.3000 & 39.1000 & 5.3461 & 2.3506 & 29.1573 \\
Minimum & -1.5000 & -19.1591 & 4.7600 & 13.7000 & 0.2632 & -2.1323 & 8.9927 \\
Std. Dev. & 2.0491 & 2.7780 & 4.8281 & 5.5064 & 1.6531 & 0.7704 & 5.7888 \\
Skewness & -0.5213 & -1.4871 & 0.2993 & 0.0466 & 0.7992 & -2.6657 & -0.9029 \\
Kurtosis & 4.0695 & 6.6163 & 1.9233 & 2.9827 & 2.1347 & 11.8810 & 2.7645 \\
Jarque-Bera & 4.2760 & 42.0209 & 2.9087 & 0.0172 & 6.3320 & 205.6557 & 6.3571 \\
Probability & 0.1178 & 0.0000 & 0.2335 & 0.9913 & 0.0421 & 0.0000 & 0.0416 \\
$\quad$ Sum & 222.50 & -381.63 & 526.09 & 1137.30 & 91.92 & 54.17 & 955.01 \\
Sum Sq. & 188.94 & 347.28 & 1048.98 & 1364.46 & 122.97 & 26.711 & 1507.98 \\
Dev. & & & & & & & \\
Observations & 46 & 46 & 46 & 46 & 46 & 46 & 46 \\
\hline
\end{tabular}

Table A3: Unit Root Test Results

\begin{tabular}{llllll}
\hline \hline Variable & Indicator & $\begin{array}{l}\text { ADF } \\
\text { Level }\end{array}$ & $\begin{array}{l}1^{\text {st }} \\
\text { Difference }\end{array}$ & $\begin{array}{l}\text { PP } \\
\text { Level }\end{array}$ & $\begin{array}{l}1^{\text {st }} \\
\text { Difference }\end{array}$ \\
\hline EG & Statistic & -2.6405 & -6.2759 & -2.6248 & -6.2758 \\
& P-Value & 0.4832 & 0.0004 & 0.5234 & 0.0002 \\
PCGDP & Statistic & 0.2425 & -2.3743 & -3.1903 & -5.7689 \\
& P-Value & 0.9976 & 0.0095 & 1.0000 & 0.0001 \\
& & & & & \\
FD & Statistic & -5.6049 & -4.2268 & -3.9809 & -10.8245 \\
& P-Value & 0.0003 & 0.0095 & 0.0161 & 0.0000 \\
\multirow{4}{*}{ LIR } & & & & & \\
& Statistic & -1.2825 & -3.4425 & -1.9394 & -11.3463 \\
& P-Value & 0.8763 & 0.0615 & 0.6175 & 0.0000 \\
GDCF & Statistic & -3.3827 & -4.6628 & -2.7336 & -7.5005 \\
& P-Value & 0.0671 & 0.0035 & 0.2287 & 0.0000 \\
\multirow{2}{*}{ OPP } & Statistic & -4.2398 & -3.6838 & -1.6216 & -7.0459 \\
& P-Value & 0.0097 & 0.0369 & 0.7685 & 0.0000 \\
\multirow{2}{*}{ POG } & Statistic & -6.0473 & -5.3151 & -7.0489 & -29.1445 \\
& P-Value & 0.0000 & 0.0006 & 0.0000 & 0.0000 \\
& & & & \\
PCR & Statistic & -2.6119 & -4.3149 & -2.0836 & -4.0352 \\
& P-Value & 0.2772 & 0.0072 & 0.5406 & 0.0145 \\
\hline
\end{tabular}

Note: Critical values are taken from MacKinnon, 1991 
Table A4: Pair-wise Granger Causality Testing

\begin{tabular}{|c|c|c|c|c|c|c|}
\hline \multirow[t]{2}{*}{ Hypothesis } & \multicolumn{2}{|c|}{ Lag 4} & \multicolumn{2}{|c|}{ Lag 3} & \multicolumn{2}{|c|}{ Lag 4} \\
\hline & $\begin{array}{c}\text { F- } \\
\text { Statistic }\end{array}$ & Prob. & $\begin{array}{c}\text { F- } \\
\text { Statistic }\end{array}$ & Prob. & $\begin{array}{c}\text { F- } \\
\text { Statistic }\end{array}$ & Prob. \\
\hline FD does not Granger Cause EG & 1.1414 & 0.3542 & 0.7365 & 0.5371 & 1.1840 & 0.3168 \\
\hline EG does not Granger Cause FD & 0.5137 & 0.7260 & 0.3645 & 0.7790 & 0.5275 & 0.5942 \\
\hline LIR does not Granger Cause EG & 1.0010 & 0.4210 & 0.8058 & 0.4989 & 1.1794 & 0.3182 \\
\hline EG does not Granger Cause LIR & 0.2859 & 0.8850 & 0.1884 & 0.9036 & 0.0844 & 0.9192 \\
\hline GDCF does not Granger Cause EG & 0.0551 & 0.9941 & 0.0254 & 0.9944 & 0.0260 & 0.9743 \\
\hline EG does not Granger Cause GDCF & 1.6463 & 0.1860 & 2.7279 & 0.0582 & 4.8547 & 0.0131 \\
\hline OPP does not Granger Cause EG & 0.4352 & 0.7821 & 0.3612 & 0.7813 & 0.2986 & 0.7435 \\
\hline EG does not Granger Cause OPP & 1.9484 & 0.1256 & 2.8738 & 0.0496 & 0.5593 & 0.5761 \\
\hline POG does not Granger Cause EG & 0.7131 & 0.5889 & 0.7180 & 0.5477 & 1.1740 & 0.3198 \\
\hline EG does not Granger Cause POG & 0.7223 & 0.5829 & 0.9832 & 0.4115 & 1.5354 & 0.2281 \\
\hline PCR does not Granger Cause EG & 0.8512 & 0.5032 & 1.2269 & 0.3140 & 0.9268 & 0.4044 \\
\hline EG does not Granger Cause PCR & 0.1490 & 0.9621 & 0.2365 & 0.8703 & 0.3485 & 0.7079 \\
\hline LIR does not Granger Cause FD & 0.6063 & 0.6609 & 0.4977 & 0.6862 & 0.1456 & 0.8649 \\
\hline FD does not Granger Cause LIR & 0.7302 & 0.5778 & 0.6697 & 0.5762 & 0.8567 & 0.4324 \\
\hline GDCF does not Granger Cause FD & 0.4799 & 0.7502 & 0.7798 & 0.5130 & 0.9053 & 0.4127 \\
\hline FD does not Granger Cause GDCF & 0.9155 & 0.4665 & 0.6425 & 0.5927 & 1.0942 & 0.3449 \\
\hline OPP does not Granger Cause FD & 2.7191 & 0.0463 & 4.6429 & 0.0076 & 7.2106 & 0.0022 \\
\hline FD does not Granger Cause OPP & 8.4343 & 0.0001 & 8.2124 & 0.0003 & 5.1087 & 0.0107 \\
\hline POG does not Granger Cause FD & 0.7279 & 0.5793 & 0.7559 & 0.5262 & 0.8484 & 0.4358 \\
\hline FD does not Granger Cause POG & 0.7792 & 0.5467 & 0.8263 & 0.4881 & 0.7612 & 0.4739 \\
\hline PCR does not Granger Cause FD & 1.1217 & 0.3630 & 0.5571 & 0.6467 & 0.3235 & 0.7255 \\
\hline FD does not Granger Cause PCR & 0.5006 & 0.7354 & 0.3553 & 0.7855 & 0.3193 & 0.7285 \\
\hline GDCF does not Granger Cause LIR & 0.5628 & 0.6912 & 1.0862 & 0.3673 & 0.9179 & 0.4078 \\
\hline LIR does not Granger Cause GDCF & 1.4490 & 0.2400 & 2.6215 & 0.0655 & 1.4116 & 0.2559 \\
\hline OPP does not Granger Cause LIR & 0.2459 & 0.9100 & 0.0715 & 0.9748 & 0.1215 & 0.8859 \\
\hline LIR does not Granger Cause OPP & 0.5855 & 0.6753 & 0.8148 & 0.4941 & 0.7070 & 0.4993 \\
\hline POG does not Granger Cause LIR & 1.2314 & 0.3165 & 1.5159 & 0.2269 & 2.2362 & 0.1204 \\
\hline LIR does not Granger Cause POG & 1.8189 & 0.1487 & 0.8314 & 0.4854 & 0.9967 & 0.3783 \\
\hline PCR does not Granger Cause LIR & 1.8505 & 0.1427 & 3.6092 & 0.0224 & 6.0325 & 0.0052 \\
\hline LIR does not Granger Cause PCR & 2.7177 & 0.0464 & 4.0666 & 0.0138 & 2.2545 & 0.1184 \\
\hline OPP does not Granger Cause GDCF & 0.3024 & 0.8742 & 1.2444 & 0.3079 & 0.8917 & 0.4181 \\
\hline GDCF does not Granger Cause OPP & 3.8990 & 0.0106 & 5.0109 & 0.0053 & 5.5880 & 0.0073 \\
\hline POG does not Granger Cause GDCF & 0.7155 & 0.5873 & 1.4532 & 0.2435 & 1.0208 & 0.3697 \\
\hline GDCF does not Granger Cause POG & 2.4762 & 0.0633 & 2.5672 & 0.0696 & 3.5243 & 0.0392 \\
\hline PCR does not Granger Cause GDCF & 0.8128 & 0.5261 & 1.5035 & 0.2301 & 1.2150 & 0.3077 \\
\hline GDCF does not Granger Cause PCR & 1.4870 & 0.2285 & 1.3028 & 0.2884 & 0.9480 & 0.3962 \\
\hline POG does not Granger Cause OPP & 0.1484 & 0.9624 & 0.2313 & 0.8740 & 0.0861 & 0.9176 \\
\hline OPP does not Granger Cause POG & 1.7526 & 0.1620 & 2.7663 & 0.0558 & 4.3086 & 0.0204 \\
\hline PCR does not Granger Cause OPP & 5.2076 & 0.0023 & 6.6531 & 0.0011 & 4.7781 & 0.0139 \\
\hline OPP does not Granger Cause PCR & 1.6105 & 0.1949 & 1.1663 & 0.3360 & 2.2162 & 0.1226 \\
\hline PCR does not Granger Cause POG & 2.69515 & 0.0477 & 3.3167 & 0.0306 & 3.5310 & 0.0390 \\
\hline POG does not Granger Cause PCR & 1.82621 & 0.1473 & 1.7629 & 0.1717 & 0.3650 & 0.6965 \\
\hline
\end{tabular}

Note: Critical values are taken from MacKinnon, 1991 
Figure A1: Behaviours of the Variables

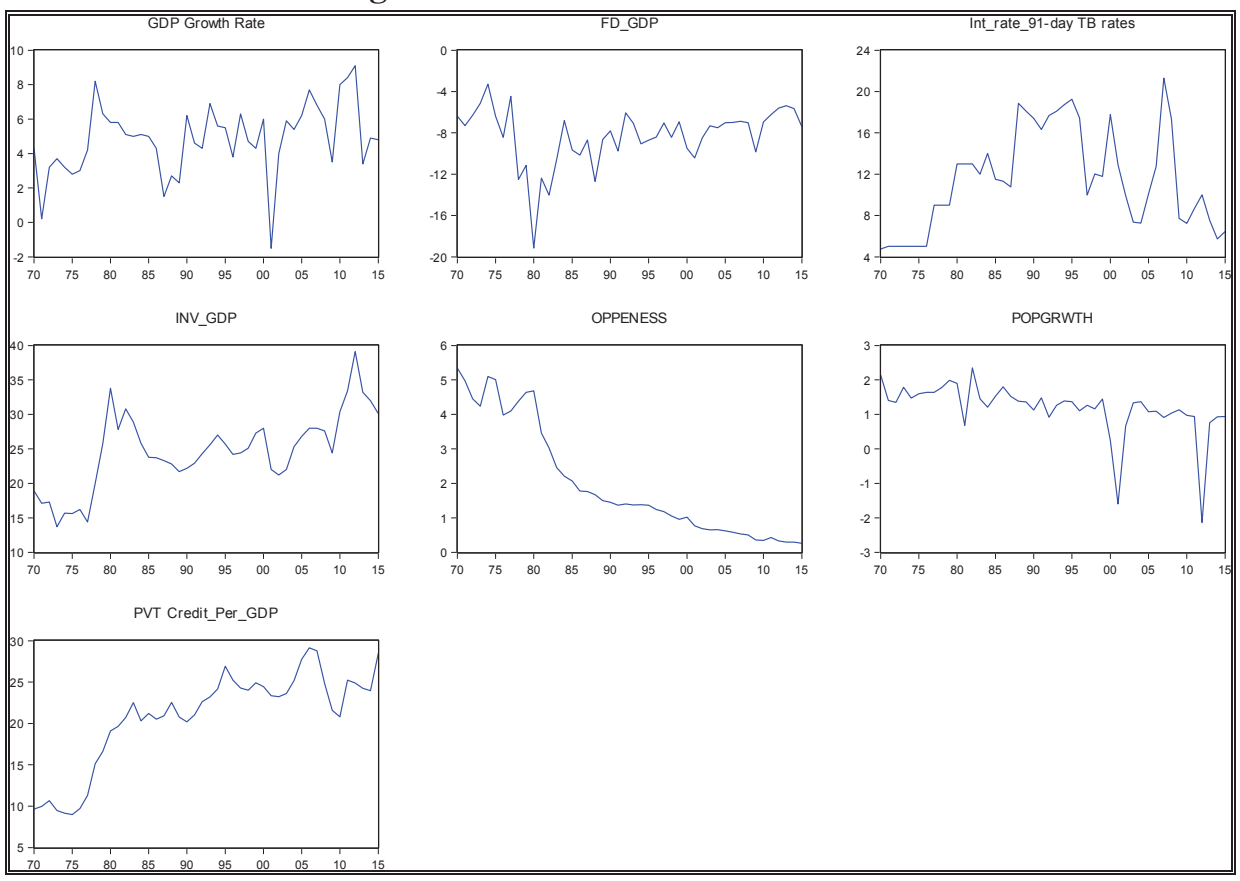

